\title{
UJI EFEK EKSTRAK ETANOL BAWANG DAYAK (ELEUTHERINE BULBOSA (MILL) URB) SEBAGAI ANTIHIPERKOLESTEROLEMIA
}

\author{
WAYAN $^{1}$, Joni Tandi ${ }^{1}$, Sri Mulyani Sabang ${ }^{2}$ dan Feiverin Tibe ${ }^{1}$ \\ ${ }^{1}$ Sekolah Tinggi Ilmu Farmasi Pelita Mas \\ ${ }^{2}$ Universitas Tadulako \\ *irien_chubby@yahoo.co.id
}

\begin{abstract}
ABSTRAK
Pada penelitian ini dilakukan uji efek ekstrak etanol bawang dayak (Eleutherine bulbosa (Mill) Urb) sebagai antihiperkolesterolemia pada tikus putih (Rattus norvegicus). Penelitian ini bertujuan untuk membuktikan kemampuan ekstrak bawang dayak dalam hiperkolesterolemia pada tikus putih, serta menentukan dosis yang efektif dalam menurunkan kadar kolesterol. Ekstrak bawang dayak diekstraksi secara meserasi dengan menggunakan pelarut etanol 96\%. Pada penelitian ini digunakan 25 ekor tikus putih yang dibagi menjadi 5 kelompok perlakuan. Pengukuran dilakukan dengan 4 kali pengukuran yaitu pengukuran awal sebelum diberi pakan, pengukuran sesudah diberi pakan diet kolesterol tinggi dan pengukuran hari ke 7 dan 14 setelah diberi ekstrak bawang dayak selama 14 hari. Kelompok I sebagai kelompok kontrol negative diberi Na CMC 0,5\%, kelompok II sebagai kelompok kontrol positif diberi simvastatin $10 \mathrm{mg}$, kelempok III,IV dan $\mathrm{V}$ diberi ekstrak bawang dayak dengan masing-masing dosis $50 \mathrm{mg} / \mathrm{dl} \mathrm{BB}$, dosis 100 $\mathrm{mg} / \mathrm{dl} \mathrm{BB}$ dan dosis $150 \mathrm{mg} / \mathrm{kg}$ BB. Data penurunan kadar kolesterol darah total dianalisis dengan menggunakan uji statistik ANOVA. Dari hasil penelitian dapat disimpulkan ekstrak bawang dayak (Eleutherine bulbosa (Mill) Urb) terbukti mampu menurunkan hiperkolesterolemia pada tikus putih yaitu pada dosis $100 \mathrm{mg} / \mathrm{dlBB}$.
\end{abstract}

Kata kunci : Bawang dayak, Antihiperkolesterolemia, Tikus putih

\begin{abstract}
This study aims to prove the ability of anion extract dayak in lowering cholesterol levels (hypercholesterolemia) to mice, and to determine the dose which is effective in lowering levels of cholesterol.ekstrak onions dayak miseration extracted by using ethanol $96 \%$. In this experiment, 25 rats were divided into 5 groups, each treatment consisted of 5 rats. Measurements were made in to four times, the initial measurement done before the rats were fed, after fedding, the measurements showed a high cholesterol diet and measurement of day 7 th and 14 after being given anion dayak extract for 14 days. Group I as a negative control which were given $\mathrm{CMC} \mathrm{Na} 0,5 \%$, group II as a positive control were given simvastatin $10 \mathrm{mg}$, groups III, IV and $V$ were given extracts of anion dayak with each dose of $50 \mathrm{mg} / \mathrm{dl} \mathrm{BB}$, a dose of $100 \mathrm{mg} / \mathrm{BB}$ dl and a dose of $150 \mathrm{mg} / \mathrm{kg}$. Reduction in total blood cholesterol levels were analyzed using statistical tests ANOVA. From this study concluded that dayak onion extract (Eleutherine bulbosa (Mill) Urb) proves to reduce total blood cholesterol levels in rats that the maximum dose of $100 \mathrm{mg} / \mathrm{dl} \mathrm{BB}$.
\end{abstract}

Keywords : Onion dayak, antihiperkolesterolemia, Rats 


\section{PENDAHULUAN}

Perkembangan zaman saat ini menimbulkan banyak alat yang dapat membuat tubuh untuk beraktifitas, tanpa perlu mengeluarkan banyak energi. Pola aktifitas ini menimbulkan terjadinya penurunan aktifitas fisik pada masyarakat dan saat ini juga terjadi peningkatan konsumsi makanan padat kalori, seperti makanan cepat saji karena sering dianggap lebih praktis dibanding makanan dengan komposisi gizi yang seimbang. Perubahan pola makan masyarakat dan aktifitas fisik tersebut dapat mengakibatkan terjadinya ketidakseimbangan energi dan dapat menyebabkan perubahan dalam pembuluh darah sehingga terjadi kolesterol.

Kolesterol merupakan penyakit yang banyak diderita oleh masyarakat saat ini, kolesterol adalah suatu lemak atau lipid golongan sterol yang diproduksi oleh tubuh. High Density Lipoprotein (HDL) merupakan suatu lipoprotein baik yang berfungsi mengangkut kembali sisa metabolisme kolesterol dalam jaringan dan mengembalikannya ke hati. HDL menjadi salah satu faktor protektif terjadinya asterosklerosis. Perubahan kolesterol metabolik dapat menyebabkan hipekolesterolemia dan itu adalah alasan utama gangguan pada kardiovaskular.

Hiperkolesterolemia merupakan salah satu faktor pemicu penyakit jantung koroner. Hiperkolesterolemia terjadi akibat adanya akumulasi kolesterol dan lipid pada dinding pembuluh darah, hiperkolesterolemia dapat berkembang menjadi aterosklerosis pada pembuluh arteri, berupa penyempitan pembuluh darah, terutama di jantung dan otak. Pencarian terhadap obat-obatan terutama obat tradisional yang berasal dari alam sangat giat dilakukan. Saat ini telah diteliti banyak tanaman yang dapat bermanfaat sebagai obat kolesterol. Salah satu jenis tanaman yang diduga dapat menurunkan kadar kolesterol dalam darah adalah bawang dayak.

Bawang dayak (Eleutherine bulbosa (Mill) Urb) merupakan tanaman khas kalimantan. Bawang dayak sering digunakan oleh masyarakat sebagai obat penurun kolesterol, diabetes dan kanker. Air rebusan atau perasan umbi bawang dayak secara tradisional diyakini mempunyai berbagai khasiat antara lain sebagai obat kanker payudara, darah tinggi (hipertensi), kencing manis (diabetes militus), kolesterol dan bisul. Kandungan bawang dayak terdiri dari senyawa alkaloid, glikosida, flavonoid, fenolik, saponin, triterpenoid, tannin, steroid, kuinon, eleutheurin, isoeleutherin dan senyawasenyawa sejenisnya, eleutherol dan eleutherinol. Potensi bawang dayak sebagai tanaman obat sangat besar namun kajian ilmiah mengenai khasiat umbi bawang dayak masih sangat sedikit.

Berdasarkan penggunaan bawang dayak sebagai obat penurun kadar kolesterol tinggi oleh masyarakat masih secara empiris dan berdasarkan latar belakang yang telah di uraikan maka peneliti tertarik untuk meneliti, apakah ekstrak bawang dayak dapat menurunkan kadar kolesterol darah pada tikus putih dan pada dosis berapakah ekstrak bawang dayak efektif dapat menurunkan kadar kolesterol yang diberikan pada tikus putih. Maksud dan tujuan dari penelitian ini adalah untuk membuktikan kemampuan ekstrak bawang dayak dalam menurunkan kadar kolesterol (hiperkolesterolemia) pada tikus putih, serta menentukan dosis yang efektif dalam menurunkan kadar kolesterol.

\section{METODE PENELITIAN \\ Bahan}

Aquadest, Alumunium foil, Alkohol 70\%, Asam klorida, Besi (III) klorida, Dragendrof, Etanol 96\%, Ekstrak bawang dayak (Eleutherine bulbosa (Mill) Urb), Hewan uji, Handskun, Kertas saring, Kuning telur bebek, Kapas, Magnesium P, Masker, Na CMC 
0,5\%, NaCl, Pakan kolesterol pig oil, Pakan standar, Simvastatin $10 \mathrm{mg}$, Tepung terigu, Tissue.

\section{Peralatan}

Batang pengaduk, Cholestest dan strip kolesterol (EasyTouch), Corong pisah, Cawan Porselin, Gelas kimia $50 \mathrm{ml}$ (pyrex), Gelas ukur $100 \mathrm{ml}$ (pyrex), Kandang hewan, Lumpang dan Alu, Lap kasar, Pipet tetes (Pyrex), Penangas air (Denville scientific), Rotavapor (Eyela N-1200 B), Rak tabung, Sonde oral, Spoit injeksi 3 ml (terumo syringe), Spoit injeksi $1 \mathrm{ml}$ (terumo syringe), Spidol, Timbangan analitik (citizen), Tabung reaksi (Pyrex), Timbangan kasar (Santorius), Wadah ekstraksi.

\section{PROSEDUR}

\section{Penyiapan dan Pengolahan Sampel}

Sampel diambil dicuci hingga bersih dengan menggunakan air yang mengalir. Selanjutnya dipotong kecil-kecil dan dikeringkan dengan cara diangin-anginkan tanpa terkena sinar matahari langsung.

\section{Pembuatan Ekstrak Umbi Bawang Dayak}

Simplisia bawang dayak diekstraksi dengan metode maserasi. Proses ini dilakukan dengan merendam serbuk bawang dayak kering dalam etanol (96\%) dalam suatu bejana. Meserasi dilakukan selama $3 \times 24$ jam dan sesekali diaduk-aduk. Maserat yang diperoleh disaring dengan meggunakan corong pisah. Maserat yang dihasilkan dikumpulkan dan diuapkan dengan menggunakan vaccum rotary evaporator dengan kecepatan $210 \mathrm{rpm}$ pada suhu $60^{\circ} \mathrm{C}$. Ekstrak yang diperoleh dipekatkan di atas penangas air sehingga diperoleh ekstrak kental.

\section{Pembuatan Suspensi Na CMC 0,5\%}

Sebanyak 0,5 g Na CMC ditaburkan dalam mortir yang berisi $10 \mathrm{ml}$ akuades yang telah dipanaskan, didiamkan selama 15 menit hingga diperoleh massa yang transparan, lalu dicampur sampai homogen. Suspensi CMC dipindahkan ke dalam labu ukur $100 \mathrm{ml}$. Volumenya dicukupkan dengan akuades hingga $100 \mathrm{ml}$.

\section{Pembuatan Suspensi Simvastatin $10 \mathrm{mg}$}

Simvastatin ditimbang sebanyak 10 tablet, lalu digerus dan ditimbang berat serbuk yang diperoleh dibagi 10 untuk memperoleh rata-rata bobot tablet adalah $153 \mathrm{mg}$ kemudian dimasukkan dalam lumpang dengan penambahan suspensi Na CMC 0,5 g sedikit demi sedikit sambil digerus hingga homogen. Memasukkan ke dalam labu takar $100 \mathrm{ml}$. Volumenya dicukupkan dengan suspensi Na CMC 0,5 g hingga $100 \mathrm{ml}$.

\section{Pembuatan Sediaan Uji}

Pembuatan ekstrak dibuat dengan menimbang sejumlah ekstrak bawang dayak sesuai dengan dosis yang diinginkan, kemudian dimasukan ke dalam labu takar $100 \mathrm{ml}$. Volumenya dicukupkan dengan suspensi Na-CMC 0,5\% hingga $100 \mathrm{ml}$.

\section{Uji Pendahuluan}

\section{Uji alkaloid}

Ditimbang 0,5 gram sampel, lalu ditambahkan $5 \mathrm{ml}$ asam klorida $2 \mathrm{~N}$ dan memanaskan di atas penangas air selama 2 menit. Setelah itu ditambahkan 2 tetes 
dragendrof LP. Jika hasil memberi endapan kuning, orange sampai merah bata maka sampel mengandung alkaloid.

\section{Uji Flavonoid}

Ditimbang 0,5 gram sampel lalu ditambahkan $5 \mathrm{ml}$ aquadest dan dipanaskan pada penangas air kemudian disaring, lalu dilarutkan dalam $0,5 \mathrm{ml}$ etanol (95\%) dan ditambahkan 0,05 gram serbuk magnesium $\mathrm{P}$, setelah itu dilarutkan dalam $5 \mathrm{ml}$ asam klorida pekat $\mathrm{P}$, jika terjadi warna merah ungu, menunjukan adanya flavonoif, jika terjadi warna kuning jingga menunjukan adanya flavonoid, kalkon dan auron.

3. Uji Saponin

Dimasukkan 0,5 gram sampel ke dalam tabung reaksi lalu ditimbahkan $10 \mathrm{ml}$ air panas kemudian didinginkan dan setelah itu kocok dengan kuat selama 10 detik. Jika terbentuk buih yang menetap selama tidak kurang dari 1 menit, setinggi $1 \mathrm{~cm}$ wampai 10 $\mathrm{cm}$ atau pada penambahan 1 tetes asam klorida buih tidak hilang maka sampel positif mengandung saponin.

4. Uji Tanin

Dimasukkan 0,5 gram sampel ke dalam tabung reaksi lalu ditambahkan aquadest 10 $\mathrm{ml}$ setelah itu dipanaskan diatas penangas air, kemudian ditambahkan larutan $\mathrm{NaCl} 10 \%$ sebanyak 3 tetes dan direaksikan dengan larutan $\mathrm{FeCl} 3$, bila terbentuk warna biru hitam menandakan adanya tanin.

5. Uji Polifenol

Dimasukkan 1 gram sampel ke dalam tabung reaksi lalu dipanaskan dalam air $5 \mathrm{ml}$ selama 10 menit dalam penangas air sampai mendidih. Setelah itu, disaring panas-panas, kemudian setelah dingin tambahkan pereaksi besi III klorida sebanyak 3 tetes. Jika terjadi warna biru menunjukan danya kandungan polifenol.

\section{Pemilihan Hewan Uji}

Hewan uji yang digunakan adalah tikus putih (Rattus norvegicus) yang memiliki kondisi tubuh yang sehat dan berumur 2-3 bulan, dengan bobot badan antara 150-250 g.

\section{Penyiapan Hewan Uji}

Hewan uji yang digunakan sebanyak 25 ekor tikus putih (Rattus norvergicus) yang dibagi menjadi 5 kelompok yang sebelumnya diadaptasikan selama 14 hari. Tiap kelompok terdiri dari 5 ekor tikus. Kelompok I sebagai kelompok kontrol negatif yang diberi suspensi Na-CMC 0,5\%. kelompok II sebagai kontrol positif yang diberi suspensi simvastatin, kelompok III, IV, V sebagai kelompok uji yang diberi ekstrak bawang dayak dengan variasi dosis $50 \mathrm{mg} / \mathrm{kg} \mathrm{BB}, 100 \mathrm{mg} / \mathrm{kg}$ BB dan $150 \mathrm{mg} / \mathrm{kg}$ BB serta, sebelum perlakuan tikus dipuasakan selama \pm 16 jam, namun tetap diberi minum ad libitium.

\section{Penyiapan Pakan Kolesterol}

Peningkatkan kadar kolesterol darah hewan uji diberikan pakan diet tinggi kolesterol. Peningkatan kadar kolesterol darah total pada hewan uji dilakukan dengan cara mencampurkan 100 gram tepung terigu, 25 gram kuning telur bebek dan 25 gram pig oil kemudian dikeringkan dengan cara disangrai kemudian ditambahkan dalam pakan standar hingga mencapai 500 gram. Makanan yang diberikan setiap harinya sebanyak 2 kali sehari.

\section{Perlakuan Terhadap Hewan Uji}

Sebelum mengukur kadar kolesterol total darah awal, hewan uji terlebih dahulu dipuasakan kurang lebih 16 jam dan sebelum diambil darahnya ekor tikus dibersihkan terlebih dahulu menggunakan alkohol, kemudian darah diambil dari ujung ekor tikus dan diteteskan kepada strip kolesterol, dalam waktu 100 detik kadar kolesterol darah secara 
otomatis akan terukur dan hasilnya dilihat pada monitor. Pada hari yang sama, tikus diinduksi dengan pemberian pakan tinggi kolesterol dua kali sehari selama 2 minggu. Setelah diinduksi, kemudian mengukur kembali kadar kolesterol darah tikus. Pada saat kadar kolesterol darah tikus telah mencapai keadaan hiperlipidemia, tikus dikelompokan. Masing-masing tikus diberi perlakuan per oral dengan menggunakan sonde oral selama 14 hari yang volumenya disesuaikan dengan berat badan tikus, diberikan 1 kali sehari. Pengukuran dilakukan dua kali yaitu hari ke-7 dan hari ke-14. Kelompok I sebagai kelompok kontrol negatif diberikan suspensi Na-CMC. Kelompok II sebagai kelompok kontrol positif dengan pemberian suspensi simvastatin. Kelompok III, IV dan V sebagai kelompok uji yang diberikan ekstrak bawang dayak dengan dosis masing-masing $50 \mathrm{mg} / \mathrm{kg}$ $\mathrm{BB}, 100 \mathrm{mg} / \mathrm{kg}$ BB dan $150 \mathrm{mg} / \mathrm{kg}$ BB. Setelah perlakuan, tikus dipuasakan lagi selama \pm 16 jam untuk pengukuran kembali kadar kolesterol darah tikus, kemudian semua data yang diperoleh dicatat dan dianalisis.

\section{HASIL DAN PEMBAHASAN}

Tabel 1. Uji fitokimia ekstrak etanol bawang dayak (Eleutherine bulbosa (Mill) Urb).

\begin{tabular}{|c|c|c|c|c|}
\hline No & $\begin{array}{c}\text { Senyawa } \\
\text { bioaktif }\end{array}$ & Pereaksi & Hasil & Keterangan \\
\hline 1 & Alkaloid & Pereaksi Dragendrof & $\begin{array}{l}\text { Terbentiknya endapan } \\
\text { merah bata }\end{array}$ & Positif \\
\hline 2 & Flavonoid & $\begin{array}{l}\text { Penambahan } \\
\text { magnesium } P \text { dan } \\
\text { HCl pekat }\end{array}$ & Terbentunya warna merah & Positif \\
\hline 3 & Saponin & $\begin{array}{l}\text { Tes pembentukan } \\
\text { busa dan penambahan } \\
\mathrm{HCl}\end{array}$ & $\begin{array}{l}\text { Adanya busa yang } \\
\text { terbentuk setinggi kurang } \\
\text { lebih } 1 \mathrm{~cm} \text { dan tetap stabil } \\
\text { selam } 5 \text { menit setelah } \\
\text { dilakukan pengocokan } \\
\text { yang kuat. }\end{array}$ & Positif \\
\hline 4 & Tanin & $\begin{array}{l}\text { Diberikan larutan } \\
\mathrm{NaCl} \text { dan } \mathrm{FeCl}_{3}\end{array}$ & $\begin{array}{l}\text { Terbentuknya warna biru } \\
\text { tua atau hijau kehitaman }\end{array}$ & Positif \\
\hline 5 & Polifenol & Penambahan $\mathrm{FeCl}_{3}$ & $\begin{array}{l}\text { Terbentuk warna hijau } \\
\text { kebiruan }\end{array}$ & Positif \\
\hline
\end{tabular}

Tabel 2. Hasil pengukuran kadar kolesterol tikus percobaan $(\mathrm{mg} / \mathrm{dl})$ sebelum diberi pakan diet kolesterol tinggi.

\begin{tabular}{cccccccc}
\hline \multirow{2}{*}{ Kelompok } & \multicolumn{5}{c}{ Ulangan } & \multirow{2}{*}{ Total } & $\begin{array}{c}\text { Rata- } \\
\text { rata }\end{array}$ \\
\cline { 2 - 6 } & 1 & 2 & 3 & 4 & 5 & & 830 \\
KP I & 180 & 161 & 154 & 150 & 185 & 166 \\
KP II & 135 & 162 & 187 & 198 & 142 & 824 & 164,8 \\
KP III & 169 & 162 & 196 & 176 & 189 & 892 & 178,4 \\
KP IV & 191 & 197 & 183 & 190 & 170 & 931 & 186,2 \\
KP V & 184 & 198 & 193 & 183 & 160 & 918 & 183,6 \\
\hline
\end{tabular}


Tabel 3. Hasil pengukuran kadar kolesterol tikus percobaan $(\mathrm{mg} / \mathrm{dl})$ sesudah diberi pakan kolesterol tinggi.

\begin{tabular}{cccccccc}
\hline \multirow{2}{*}{ Kelompok } & \multicolumn{5}{c}{ Ulangan } & Total & $\begin{array}{c}\text { Rata- } \\
\text { rata }\end{array}$ \\
\cline { 2 - 6 } & 1 & 2 & 3 & 4 & 5 & & 243,2 \\
KP I & 235 & 226 & 244 & 250 & 261 & 1216 & 243,4 \\
KP II & 250 & 291 & 248 & 259 & 214 & 1262 & 252,4 \\
KP III & 239 & 245 & 261 & 239 & 234 & 1227 & 245,4 \\
KP IV & 239 & 282 & 262 & 264 & 244 & 1291 & 258,2 \\
KP V & 291 & 234 & 362 & 280 & 285 & 1452 & 290,4 \\
\hline
\end{tabular}

Tabel 4. Hasil pengukuran kadar kolesterol tikus percobaan (mg/dl) hari ke-7 setelah diberi ekstrak bawang dayak (Eleutherine bulbosa (Mill) Urb).

\begin{tabular}{|c|c|c|c|c|c|c|c|}
\hline \multirow{2}{*}{ Kelompok } & \multicolumn{5}{|c|}{ Ulangan } & \multirow{2}{*}{ Total } & \multirow{2}{*}{$\begin{array}{c}\text { Rata- } \\
\text { rata }\end{array}$} \\
\hline & 1 & 2 & 3 & 4 & 5 & & \\
\hline KP I & 234 & 228 & 243 & 238 & 248 & 1191 & 238,2 \\
\hline KP II & 209 & 241 & 224 & 226 & 196 & 1096 & 219,2 \\
\hline KP III & 236 & 243 & 237 & 212 & 236 & 1164 & 232,8 \\
\hline KP IV & 221 & 238 & 218 & 235 & 239 & 1151 & 230,2 \\
\hline KP V & 223 & 210 & 253 & 229 & 225 & 1140 & 228 \\
\hline
\end{tabular}

Tabel 4. Hasil pengukuran kadar kolesterol tikus percobaan $(\mathrm{mg} / \mathrm{dl})$ hari ke-14 setelah diberi ekstrak bawang dayak (Eleutherine bulbosa (Mill) Urb).

\begin{tabular}{|c|c|c|c|c|c|c|c|}
\hline \multirow{2}{*}{ Kelompok } & \multicolumn{5}{|c|}{ Ulangan } & \multirow{2}{*}{ Total } & \multirow{2}{*}{$\begin{array}{c}\text { Rata- } \\
\text { rata }\end{array}$} \\
\hline & 1 & 2 & 3 & 4 & 5 & & \\
\hline KP I & 222 & 232 & 239 & 236 & 248 & 1177 & 235,4 \\
\hline KP II & 176 & 199 & 197 & 183 & 153 & 908 & 181,6 \\
\hline KP III & 232 & 240 & 234 & 210 & 227 & 1143 & 228,6 \\
\hline KP IV & 186 & 193 & 178 & 199 & 196 & 952 & 190,4 \\
\hline KP V & 184 & 178 & 195 & 174 & 189 & 920 & 184 \\
\hline
\end{tabular}

Tabel 6. Hasil selisih penurunan kadar kolesterol darah total pada tikus putih pada hari ke7 dan ke-14.

\begin{tabular}{clccccc}
\hline \multirow{2}{*}{ No. } & \multirow{2}{*}{ Kelompok } & \multicolumn{4}{c}{ Selisih penurunan kadar kolesterol } \\
\cline { 3 - 6 } & & \multicolumn{3}{c}{ Hari ke-7 } & Hari ke-14 \\
\hline 1 & Kontrol (-) & 7 & A & 7,8 & A \\
2 & $50 \mathrm{mg} / \mathrm{dl} \mathrm{BB}$ & 12,6 & $\mathrm{~A}$ & 16,8 & $\mathrm{~A}$ \\
3 & $100 \mathrm{mg} / \mathrm{dl} \mathrm{BB}$ & 28 & $\mathrm{~A}$ & 65,8 & $\mathrm{~B}$ \\
4 & Kontrol (+) & 33,2 & $\mathrm{~A}$ & 70,2 & $\mathrm{~B}$ \\
5 & $150 \mathrm{mg} / \mathrm{dl} \mathrm{BB}$ & 62,4 & $\mathrm{~B}$ & 106,4 & $\mathrm{~B}$ \\
\hline
\end{tabular}

Keterangan :

$\mathrm{A}=$ Tidak berbeda nyata

$\mathrm{B}=$ berbeda nyata

Pada hari ke-7 kontrol negatif, dosis $50 \mathrm{mg} / \mathrm{dlBB}$, dosis $100 \mathrm{mg} / \mathrm{dlBB}$ dan kontrol positif tidak berbeda nyata (A) sedangkan pada dosis $150 \mathrm{mg} / \mathrm{dlBB}$ hasil yang diperoleh berbeda nyata (B) dengan kelompok lain, sehingga dilanjutkan pada hari ke-14. Pada hari 
ke-14 kontrol negatif dan dosis $50 \mathrm{mg} / \mathrm{dlBB}$ memperoleh hasil yang tidak berbeda nyata (A). Sedangkan pada dosis $100 \mathrm{mg} / \mathrm{dlBB}$, kontrol positif dan dosis $150 \mathrm{mg} / \mathrm{dlBB}$ memperoleh hasil berbeda nyata (B) dengan kelompok kontrol negatif dan dosis 50 $\mathrm{mg} / \mathrm{dlBB}$. Sehingga pada dosis $100 \mathrm{mg} / \mathrm{dlBB}$ memiliki nilai hampir setara dengan kontrol positif (simvastatin) yang menandakan dosis $100 \mathrm{mg} / \mathrm{dlBB}$ merupakan efek yang efektif.

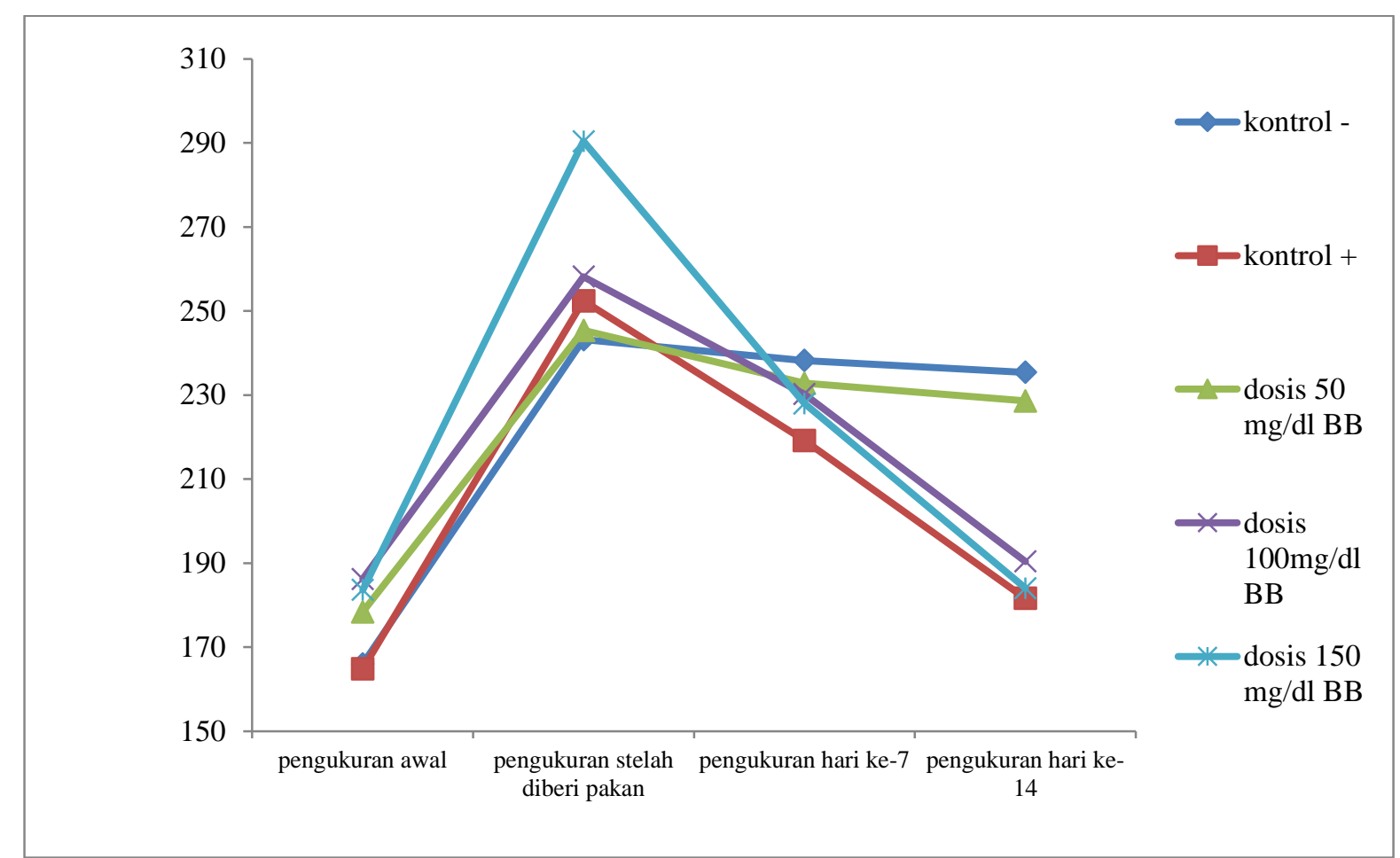

Kurva 1. Hasil pengukuran kadar kolesterol darah total tikus pada berbagai dosis ekstrak bawang dayak (Eleutherine bulbosa (Mill) Urb).

Hasil yang diperoleh menunjukan rerata kadar kolesterol awal tikus percobaan relative berbeda antara kelompok satu terhadap kelompok yang lainnya. Kadar kolesterol tikus kelompok IV relative lebih tinggi $(186,2 \mathrm{mg} / \mathrm{dl})$ dibandingkan dengan kelompok lainnya, sedangkan kadar kolesterol yang relative rendah yaitu pada kelompok II (164,8 $\mathrm{mg} / \mathrm{dl}$ ) dibandingkan dengan kelompok lainnya.

Tikus percobaaan yang dikehendaki adalah tikus dengan kadar kolesterol tinggi (hiperkolesterolemia). Untuk mendapatkan tikus dengan kadar dengan kolesterol tinggi, diberi pakan kolesterol tinggi selama 14 hari setelah masa adaptasi, Selanjutnya diukur kadar kolesterol darah totalnya. Hasil yang diperoleh 3 menunjukan semua tikus percobaan kadar kolesterol diatas $200 \mathrm{mg} / \mathrm{dl}$. Kadar kolesterol tertinggi (290,4 mg/dl) ditemukan pada tikus kelompok III dan kadar kolesterol terendah $(243,2 \mathrm{mg} / \mathrm{dl})$ ditemukan pada tikus kelompok I. Kenaikan kadar kolesterol total (dari kadar kolesterol awal ke kadar kolesterol setelah pemberian pakan) tertinggi $(290,4 \mathrm{mg} / \mathrm{dl}-183,6 \mathrm{mg} / \mathrm{dl}=106,8 \mathrm{mg} / \mathrm{dl})$ ditemukan pada tikus kelompok V (KP V) dan kenaikan kadar kolesterol darah terendah $(245,4$ $\mathrm{mg} / \mathrm{dl}-178,4 \mathrm{mg} / \mathrm{dl}=67 \mathrm{mg} / \mathrm{dl})$. Hal tersebut memberikan petunjuk pakan kolesterol tinggi yakni, pakan yang mengandung kuning telur dan pig oil mampu meningkatkan kadar kadar kolesterol tikus percobaan.

Pada pengaruh konsentrasi ekstrak bawang dayak (Eleutherine bulbosa (Mill) Urb) terhadap penurunan kadar kolesterol total darah, pemberian pakan berkolesterol tinggi 
dihentikan selama 14 hari dan diganti dengan pakan standar dan diberi ekstrak bawang dayak dengan berbagai konsentrasi selama 14 hari dengan dua kali pengukuran yaitu pada hari ke-7 dan ke-14 hari. Pada hari ke-7 dilakukan pengukuran kadar kolesterol total darah tikus percobaan. Hasil yang diperoleh menunjukan kadar kolesterol tikus percobaan belum mengalami penurunan yang signifikan sehingga dilanjutkan pada pengukuran hari ke 14 . Pada hari ke-14 dilakukan pengukuran kadar darah tikus percobaan. Hasil yang diperoleh (gambar 4.5) menunjukan kadar kolesterol tikus percobaan pada hari ke 14 mengalami perbedaan yang berbeda sangat nyata. Kadar kolesterol tertinggi $(235,4 \mathrm{mg} / \mathrm{dl})$ ditemukan pada tikus kelompok I dan kadar kolesterol terendah $(184 \mathrm{mg} / \mathrm{dl})$ ditemukan pada kelompok V. Penurunan kadar kolesterol darah (dari kadar kolesterol setelah pemberian pakan sampai diberikan ekstrak pada hari ke-14) tertinggi (290,4 mg/dl -184 mg/dl = 106,4 $\mathrm{mg} / \mathrm{dl}$ ) ditemukan pada tikus kelompok V (KP V). Penurunan kadar kolesterol darah terendah $(243,2 \mathrm{mg} / \mathrm{dl}-235,4 \mathrm{mg} / \mathrm{dl}=7,8 \mathrm{mg} / \mathrm{dl})$ ditemukan pada tikus kelompok I, yakni yang tidak diberi ekstrak bawang dayak atau kontrol (-). Penurunan kelompok V tersebut mendekati dua kali lipat atau 100\%, dengan demikian dapat disimpulkan ekstrak bawang dayak mampu menurunkan kadar kolesterol darah tikus percobaan.

Penentuan adanya efek penurunan kadar kolesterol dari variasi dosis ekstrak bawang dayak dilakukan dengan uji statistik Analisis Sidik Ragam (ANSIRA) dengan taraf kepercayaan 95\%. Berdasarkan hasil perhitungan pada hari ke-14 diperoleh hasil bahwa Fhitung $=16,14>$ Ftabel pada taraf signifikan $5 \%=3,01$ maupun $1 \%=4,77$. Hasil yang diperoleh menunjukan konsentrasi ekstrak bawang dayak (Eleutherine bulbosa (Mill) Urb) berpengaruh sangat nyata terhadap penurunan kadar kolesterol darah tikus percobaaan. Hal ini berarti dosis $100 \mathrm{mg} / \mathrm{kg} \mathrm{BB}, 150 \mathrm{mg} / \mathrm{kg}$ BB ekstrak bawang dayak memberikan pengaruh terhadap penurunan kadar kolesterol total darah tikus.

Berdasarkan Koefisien Keseragaman (KK) data hasil pengukuran diketahui pada hari ke-14 diperoleh 5,65\%, maka dilakukan uji lanjut dengan menggunakan uji Beda Nyata Jujur (BNJ). Berdasarkan hasil uji tersebut pada hari yang ke-14 diketahui bahwa kelompok dengan variasi dosis ekstrak bawang dayak $100 \mathrm{mg} / \mathrm{kg} \mathrm{BB}, 150 \mathrm{mg} / \mathrm{kg} \mathrm{BB}$, dan kelompok kontrol positif memberikan hasil yang berbeda nyata. Pada kelompok perlakuan kontrol negatif dan dosis $50 \mathrm{mg} / \mathrm{kg}$ BB memberikan hasil yang tidak berbeda nyata. Namun dari ketiga variasi dosis konsentrasi yang digunakan pemberian ekstrak bawang dayak pada dosis $100 \mathrm{mg} / \mathrm{kg}$ BB memberikan hasil maksimal dan pemberian ekstrak bawang dayak pada dosis $150 \mathrm{mg} / \mathrm{kg}$ BB memberikan hasil yang paling maksimal. Maka dapat dinyatakan bahwa semakin tinggi dosis yang digunakan maka dapat meningkat penurunan kadar kolesterol darah tikus. Hal ini disebabkan karena fitokimia yang semakin banyak dalam ekstrak bawang dayak yaitu berupa flavonoid, saponin dan serat sehingga dapat menurunkan kadar kolesterol darah.

\section{Kesimpulan}

Berdasarkan hasil penelitian maka dapat disimpulkan :

1. Ekstrak bawang dayak (Eleutherine bulbosa (Mill) Urb) terbukti mampu menurunkan kadar kolesterol darah total pada tikus putih.

2. Ekstrak bawang dayak (Eleutherine bulbosa (Mill) Urb) dengan konsentrasi100 mg/kg BB merupakan dosis yang efektif terhadap penurunan kadar kolesterol darah tikus putih.

\section{DAFTAR PUSTAKA}

1. Wijayakusuma, H., 1995. Tanaman Berkhasiat Obat Di Indonesia, Ed. IV. Penerbitan Pustaka Kartini, Jakarta. hal 12-19 
2. Uneputy, piere.2013. Potensi Infusa Daun Sirsak terhadap kadar kolesterol darah tikus putih jantan.Unsrat. Manado. Hal 111-116

3. Anonim, "Sarang Semut Dan Herbal Bawang Dayak Diminati", http : // koran kaltim. com/ index, Samarinda, 2008, 31 Oktober 2008, pk.20.37, hal 1-2.

4. Saptowalyono, C.A., "Bawang Dayak, Tanaman Obat Kanker Yang Belum Tergarap", http : // www2. kompas. com/ ver1/ Kesehatan/ 0702/ 19/ 170611. htm, Palangkaraya, 2007, 31 Oktober 2008, pk. 20.28, hal 1,3.

5. Megawati, Y.S., 2005 ."Pengujian Daya Hambat Ekstrak Metanol Bawang Dayak (Eleutherine palmifolia (L) Merr) Terhadap Pertumbuhan Bakteri Staphylococcus aureus Dan Bacillus substilis”, KTI Akademi Farmasi Pontianak, Yayasan Rumah Sakit Islam, Pontianak, hal 6.

6. Heyne, K., 1987. "Tumbuhan Berguna Indonesia", Jilid I, Badan Penelitian dan Pengembangan Kehutanan Departemen Kehutanan, Jakarta, hal 551-552.

7. Anonim,. 1978. “Tumbuhan Obat”, Lembaga Biologi Nasional-LIPI, Bogor, hal 15-17.

8. Firdaus, Rininta,. 2006. "Telaah Kandungan Kimia Ekstrak Metanol Umbi Bawang Tiwai (Eleutherine americana (Aubl.) Merr.)", Skripsi Institut Teknologi Bandung, Bandung, hal 4-5.

9. Sangat, Zuhud dan Damayanti. 2000. "Kamus Penyakit Dan Tumbuhan Obat Indonesia (Etnofitomedika)", Yayasan Obor Indonesia, Jakarta, hal xi, 14 dan 153.

10. Alfinda Novi Kristanti. 2008.Buku Ajar Fitokimia. Air Langga. University Press. Surabaya. Hal. 53-57.

11. Malole, M.M.B, Pramono, C.S.U., (1989), “ Penggunaan Hewan-hewan Percobaan Laboratorium", Penelaah Maskudi Pertadireja, Departemen Pendidikan dan Kebudayaan, Direktorat Jenderal Pendidikan Tinggi Pusat Antar Universitas Bioteknologi, IPB, Bogor. Hal 26-30

12. Fahrudiasah. 2012. Potensi Ekstrak Kulit Kayu Mahoni Sebagai Penurun KolesterolDarah Pada Tikus Putih HIPERKOLESTEROLEMIA. Fakultas Matematika Dan Ilmu Pengetahuan Alam. Institut Pertanian Bogor. Hal 67-71

13. Hernawati,.2008. Peranan Berbagai Sumber Serat Dalam Dinamika Kolesterol

Pada Individu Hiperkolesterolemia dan normokolesterolemia, FMIPA Universitas Pendidikan Indonesia. Hal 53,55

14. Cheung, Alfred K., DeVault, George A., Gregory, Martin C., 1993. A Prospective Study on Treatment of Hypercholesterolemia With Lovastatin in Renal Transplant Patients Receiving Cyclosporine. Journal of The American Society of Nephrology Vol.3 Number 12. 1884-1891.

15. Anonim 2007. Fitosterol, lawan Kolesterol, Kanker Dan Penuaan, gayahidupsehat. (14 agustus 2012).

16. Zulkarnain, Prakoso. 2006. Pengaruh Pemberian Vitamin C Terhadap Kadar LDL dan HDL Kolesterol Serum Wistar Jantan (Rattus norvegicus) Hiperlipidemia Setelah Perlakuan Jus Lidah Buaya (Aloe verra Linn.). [Skripsi] Fakultas Kedokteran. Universitas DiPonegoro. Semarang. Hal 18-20

17. I Wayan Sumardika. 2012. Ekstrak Air Ubi Jalar Ungu Memperbaiki Profil Lipid Dan Meningkatkan Kadar SOD Darah Tikus Yang Diberi Makan Tinggi Kolesterol. Jurnal Ilmiah Kedokteran. Vol.43 No.2. Bali.hal 2-4,6

18. Iman Soeharto. 2001. Kolesterol dan Lemak Jahat, Kolesterol dan Lemak Baik dan Proses Terjadinya Serangan Jantung Dan Stroke. PT. Gramedia Pustaka Utama. Jakarta. Hal. 30-40, 45, 48, 84

19. Hoan Tjay. 2008. Obat-Obat Penting. Edisi Ke-Enam. Penerbit PT. Elex Media Komputindo. Gramedia. Jakarta. Hal. 569-583 
20. Siti Arum. 2012. Kandungan Nutrisi, Komposisi Asam Lemak Dan Kadar Kolesterol Domba Garut Muda Berbeda Umur Yang Diberi Ransum Mengandung Limbah Tauge. [Skripsi]. Fakultas Peternakan. Institut Pertanian Bogor. Hal12-13

21. Meisa Marsalina. 2010. Pengaruh Pemberian Ekstrak air Kelopak Bunga Rosela (Hibiscus sabdariffa L.) Terhadap kadar Kolesterol Total Darah Dan Berat Badan Tikus Putih (Rattus norvegicus). [Skripsi]. Fakultas Kedokteran. Universitas Sebelas Maret. Suryakarta. Hal 5-6

22. Petrus Dan Johannes. 1991. Patologi Klinik. Edisi IV. Penerbit EGC. Jakarta. Hal. 9395

23. Siti Arum. 2012. Kandungan Nutrisi, Komposisi Asam Lemak Dan Kadar Kolesterol Domba Garut Muda Berbeda Umur Yang Diberi Ransum Mengandung Limbah Tauge. [Skripsi]. Fakultas Peternakan. Institut Pertanian Bogor. Hal 12-14

24. Ichsan, Wiryandi, Usmar dan Burhanuddin T. 2011. Uji Efek Hipokolesterolemik Sari Buah Terong Belanda (Cyphomandra betaceae Sendt.) Pada Tikus Putih (Rattus novergicus). [Skripsi]. Fakultas Farmasi, Universitas Hasanuddin, Makassar. Hal.6364

25. Eleanor Dan Jonathan. 2007. Kolesterol. Erlangga. Jakarta. Hal.1-3

26. Mutschler E. 1999. Dinamika Obat. Edisi Ke V. Cetakan Ketiga. Institut Teknologi Bandung. Bandung. Hal. 434-435;437;437-440

27. Deherba, 2012. Famili Madika. Apakah obat-obatan diperlukan untuk mengatasi kolesterol berlebihan. Hal 15-18

28. Lehninger, Albert L. 2005. Dasar-Dasar Biokimia. Jilid 2. Diterjemahkan oleh : Maggy Thenawidjaya. Penerbit Erlangga. Hal 24-26

29. Fifteen Aprilia. 2010. Aktivitas Ekstrak Etanol Ketan Hitam Untuk Menurunkan Kadar Kolesterol. Jurnal Farmasi Indonesia Vol.5 No.2 : 63-69

30. Zaimah Z. Dr. 2009 . Manfaat Serat. [Skripsi] Departemen Ilmi Gizi. Fakultas Kedokteran Universitas Sumatera Utara. Hal 59-61 